\title{
MOLECULAR MONITORING IN ACUTE MYELOID LEUKEMIA PATIENTS UNDERGOING MATCHED UNRELATED DONOR - HEMATOPOIETIC STEM CELL TRANSPLANTATION: SINGLE CENTER EXPERIENCE
}

\author{
Irina Panovska-Stavridis ${ }^{1}$, Aleksandra Pivkova-Veljanovska ${ }^{1}$, Nevenka Ridova ${ }^{1}$, Zlate Stojanovski ${ }^{1}$,

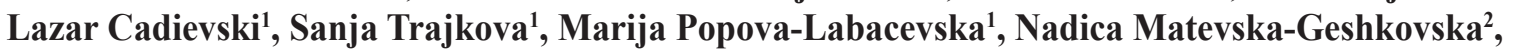 \\ Lidija Cevreska $^{1}$, Borche Georgievski ${ }^{1}$, Aleksandar Dimovski ${ }^{2,3}$ \\ ${ }^{1}$ University Clinic of Hematology-Skopje, RN Macedonia \\ ${ }^{2}$ Center for Biomolecular Pharmaceutical Analyses, UKIM -Faculty of Pharmacy, University "Ss Cyril and Methodius", Skopje, \\ RN Macedonia \\ ${ }^{3}$ Research Center for Genetic Engineering and Biotechnology "Georgi D. Efremov", Macedonian Academy of Sciences and \\ Arts, Skopje, RN Macedonia
}

Corresponding author: Irina Panovska-Stavridis, MD, $\mathrm{PhD}$, University Clinic of Hematology-Skopje, Republic of North Macedonia, Majka Tereza 17, 1000 Skopje, RN Macedonia, tel/fax:+389 2 3111749, e-mail: dr irina@yahoo. com; Aleksandar Dimovski,MD,PhD, Center for Biomolecular Pharmaceutical Analyses, UKIM - Faculty of Pharmacy, Majka Tereza 46, 1000 Skopje RN Macedonia and Research Center for Genetic Engineering and Biotechnology "Georgi D. Efremov" Macedonian Academy of Sciences and Arts Bul. Krste Misirkov 2, 1000 Skopje, RN Macedonia, tel:+389 2 3119694; +389 2 3235411, e-mail: adimovski@ff.ukim.edu.mk; a. dimovski@manu.edu.mk

\section{ABSTRACT}

Introduction: Minimal residual disease (MRD) assessment in acute myeloid leukemia (AML) cases is a complex, multi-modality process and, though much of its clinical implications at different points are extensively studied, it remains even now a challenging area. It is a disease the biology of which governs the modality of MRD assessment; in patients harboring specific molecular targets, high sensitivity techniques can be applied. On the other hand, relapse is considered as the leading cause of treatment failure in AML patients undergoing allogeneic hematopoietic stem cell transplantation (alloHSCT).

Materials and methods: Since November 2018 until June 2020, 10 AML patients underwent matched unrelated donor (MUD) HSCT at the University Clinic of Hematology-Skopje, Republic of North Macedonia. Molecular markers were identified in a total of 4 patients; 3 patients expressed chimeric fusion transcripts; two RUNX-RUNX1T1 and one for CBFB-MYH11. One patient harbored mutation in the transcription factor CCAAT/enhancer binding protein $\alpha$ (CEBPA). Post-transplant MRD kinetics was evaluated by using quantitative polymerase chain reaction (RT-qPCR) or multiplex fluorescent-PCR every three months during the first two years after the transplantation.

Results: MRD negativity was achieved in three pre-transplant MRD positive patients by the sixth month of HSCT. They sustained hematological and molecular remission for 19, 9 and 7 months, respectively. The fourth patient died due to transplant-related complications.

Conclusion: According to our experience, when molecularly-defined AML patients undergo HSCT, regular MRD monitoring helps predict impending relapse and direct future treatment strategies.

Keywords: minimal residual disease (MRD), molecular monitoring, matched unrelated donor (MUD) hematopoietic stem cell transplantation (HSCT), acute myeloid leukemia (AML), RUNX-RUNX1T1, CBFB-MYH11, CEBPA

\section{INTRODUCTION}

Acute myeloid leukemia (AML) is a heterogeneous disease, defined by the presence of several germline mutations and distinct molecular subgroups. Allogeneic hematopoietic stem cell transplantation (alloHSCT) plays a central role in the management of patients with AML, making the AML one of the com- 
monest indications for alloHSCT. By overcoming the limitations of donor availability in the recent years, as well as advances in the transplant procedures and post-transplant strategies, alloHSCT evolved into a definite curative option for a significant number of AML patients. [1] However, despite the changing landscape of AML and novel treatment paradigm, the relatively high mortality rate due to relapse after alloHSCT is still discouraging. Data from the Center for International Blood and Marrow Transplant Research (CIBMTR) report $63 \%$ mortality rate in patients undergoing unrelated donor HSCTs due to transplant-related events, including graft-vs.-host disease, infection and other causes - organ toxicity or second malignancies, compared to $37 \%$ of deaths due to relapse [2]. This high relapse ratio suggests that significant residual leukemic cell populations capable of causing relapse survive the transplant procedure. The proportion of these cells, relative to their ratio at diagnosis, is referred to as a measure of minimal residual disease (MRD). It is believed that these cell populations are present even up to several months before apparent morphological changes occur. At this point the imminent relapse can be solely detected with high sensitivity methods. In post-transplant setting, the prime aim of MRD evaluation is to detect impending relapse and thus identify patients who may benefit from early clinical intervention $[3,4]$. Several studies to date have demonstrated the prognostic value of MRD negativity, defined by established cutoff ranges, on post- transplant outcome [5]. Therefore, the 2017 European LeukemiaNet (ELN) consensus document on MRD in AML denotes MRD negative $\mathrm{CR}$ as an endpoint [3, 4]. A number of methods are employed for MRD measurement, but the question remains whether the biology of the disease itself governs the modality of MRD assessment. In general, two methods are commonly incorporated into a clinical routine: multiparameter flow cytometry (MFC) which allows detection of aberrant immunophenotypes and molecular methods for the detection of tumor-specific molecular defects, such as RT-qPCR [3]. PCR-based MRD assessment gives sensitivity of $1: 10-5$ to $1: 10-6$, which means 100-1.000 times greater sensitivity than that of other methods applied $[3,6]$. However, it is restricted to those harboring specific molecular targets that can be tracked for MRD monitoring. Unfortunately, less than half of the patients (35\% in the older population, with frequency decreases with age) harbor detectable molecular mutations. More precisely, PCR-based MRD monitoring is proposed for AML with validated molecular markers such as mutations in the gene encoding nucleophosmin (NPM1) and the chimeric fusion genes RUNX1- RUNX1T1, CBFB-MYH11 and PML-RARA [3]. In patients undergoing HSCT, an MRD assessment is recommended within one month prior to the procedure, a follow-up every three month for at least two years during the post-transplant period and follow-up based on individual risk thereafter [7].

In this paper, we present four AML patients harboring specific genetic aberrations, who underwent MUD - HSCT; two of them carrying RUNX1-RUNX1T1 transcript, one patient with CBFB-MYH11 transcript and 1 patient with mutation in CEBPA. During the post-transplant follow-up, we used RT-PCR method to monitor the molecular response in these patients by tracking the initially detected markers at defined time points. We also present our initial experience of the clinical implication MRD status on the clinical decisions and further management of these patients.

\section{MATERIAL AND METHODS}

Since the introduction of the MUD-HSCT at the University Clinic for Hematology in Skopje, Republic of North Macedonia, in November 2018, until the end of June 2020, 10 AML patients underwent MUD HSCT. Molecular markers were identified in a total of 4 patients; two of these patients were positive for the RUNX-RUNX1T1 transcript, 1 patient for the CBFB-MYH11 transcript and 1 patient had mutation in the CEBPA gene. The patients' individual characteristics are summarized in Table 1. Two patients were diagnosed with "de novo" AML and the other two patients had secondary AML, evolving from antecedent myelodysplasia and myeloid sarcoma, respectively. All patients underwent transplantation in the first complete hematological remission, defined as $<5 \%$ blasts in bone marrow and complete recovery of peripheral blood count [8]. Three patients received conditioning regimen considered myeloablative [9] with Bu-Cy + ATG and the last patient received reduced intensity chemotherapy regimen with Bu-Flu + ATG. Peripheral blood stem cells were used as graft source in all patients. The patients underwent HSCT between November 2018 and January 2020. In the post-transplant period, bone marrow samples for MRD monitoring were obtained at scheduled time points; the first one within two months of HSCT and the next four at $+3,+6,+9$ and +12 months of HSCT. The cut-off date for follow-up was June 30, 
2020. Median follow-up time was 8 months (range: 3-19 months).

Post-transplant MRD kinetics was evaluated by using quantitative polymerase chain reaction (RT-qPCR) or multiplex fluorescent-PCR every three months after the transplantation. Molecular analyses were performed at the Center for Biomolecular Pharmaceutical Analyses, UKIM-Faculty of Pharmacy, Skopje in bone marrow aspirates. RT- PCR is a high sensitivity method to detect the presence of leukemia cells down to levels of 1:10-5 to 1:10-
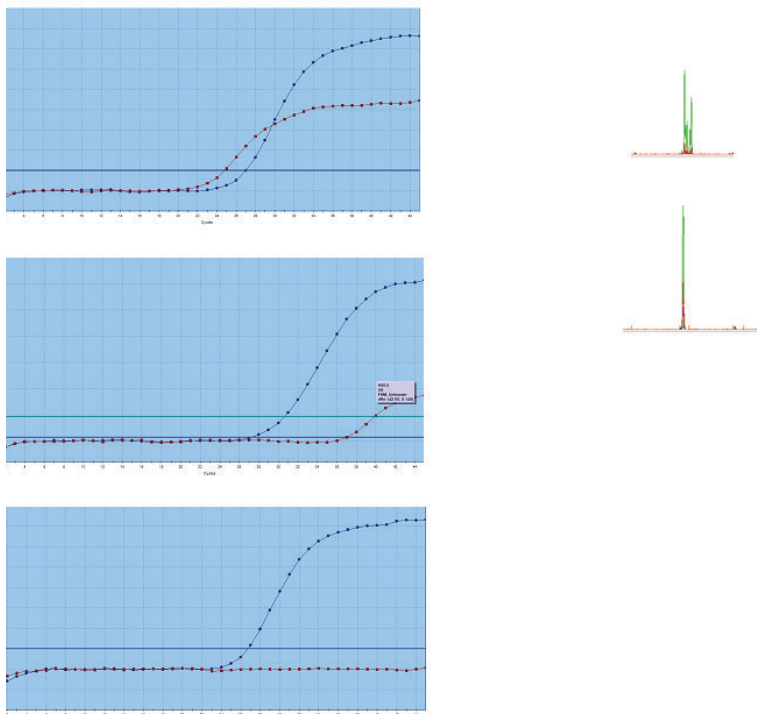

Figure 1. MRD analyses using the AML-ETO hybrid transcript $(\mathrm{A}, \mathrm{B}, \mathrm{C})$ or CEBPA mutation (D, E) molecular markers performed at diagnosis (A and D), pre-transplantation (B) and one month after transplantation $(\mathrm{C}$ and $\mathrm{E})$. The blue circles and red squares in (A), (B) and (C) indicate the strength of the fluorescent signal generated during the RT/PCR amplification of the internal control $\mathrm{ABL}$ and hybrid AML-ETO transcripts, respectively. The arrow in (D) indicates the detection of the $5 \mathrm{bp}$-del mutant allele in the CEBPA gene. Table 1. Individual and clinical pre-HSCT characteristics of analyzed AML patients.

\begin{tabular}{|c|c|c|c|c|}
\hline & Patient 1 & Patient 2 & Patient 3 & Patient 4 \\
\hline Age at diagnosis & 22 & 21 & 58 & 37 \\
\hline Sex & Male & male & Female & Female \\
\hline Comorbidities & No & No & No & No \\
\hline $\begin{array}{l}2017 \text { ELN risk } \\
\text { stratification }^{16}\end{array}$ & Favorable & favorable & favorable & Favorable \\
\hline Molecular marker & $\begin{array}{l}\text { CBFB-MYH11 } \\
\text { inv(16)(p13q22) }\end{array}$ & $\begin{array}{l}\text { RUNX-RUNX1T1 } \\
\text { t(8;21)(q22;q22) }\end{array}$ & $\begin{array}{l}\text { CEBPA 5nt } \\
\text { del }\end{array}$ & $\begin{array}{l}\text { RUNX-RUNX1T1 } \\
\text { t(8;21)(q22;q22) }\end{array}$ \\
\hline Number of induction & 2 & 2 & $\begin{array}{c}3 \\
(2+1)\end{array}$ & 2 \\
\hline $\begin{array}{c}\text { Number of consolidation } \\
\text { therapies }\end{array}$ & 2 & 2 & $(2,1)$ & 2 \\
\hline Time to HSCT & 6 months & 7 months & 15 months & 6 months \\
\hline $\begin{array}{c}\text { Disease status prior } \\
\text { HSCT }\end{array}$ & CR1 & CR1 & CR1 & CR1 \\
\hline MRD status prior HSCT & $\begin{array}{l}\text { MRD + } \\
(0.15 \%)\end{array}$ & $\mathrm{MRD}+(0.20 \%)$ & MRD + & MRD + $(0.09 \%)$ \\
\hline
\end{tabular}
(MNCs) were isolated by Ficoll density gradient. Detailed procedures for MRD assays detecting RUNX1-RUNX1T1, CBFB-MYH11 and CEBPA gene mutations have been published by the Europe Against Cancer Initiative [9]. The samples were run in triplicate. The molecular response was expressed as $\log$ reduction of transcript levels. MRD positivity was defined according to the Europe Against Cancer Program Criteria (amplification in at least 2 out of 3 replicates with cycle-threshold values of 40 or less, using a threshold setting of 0.1) [10]. The presence of mutations in the CEBPA gene was evaluated by multiplex fluorescent PCR analysis covering the coding region of the CEBPA gene and the exact molecular defects of all additional fragments was analyzed by Sanger sequencing [11]. Representative results of these analyses for the detection of the AML-ETO hybrid transcript and the mutation in the CEBPA gene are shown in Figure 1.

\section{RESULTS}

\section{Case presentations}

Case I

A young man at the age of 22 was admitted to our clinic in March 2018 with histological diagnosis of myeloid sarcoma of surgically resected intestinal tumor mass. AML was manifested 3 months later and induction and re-induction chemotherapy with standard 3+7 DA regimen was applied followed by two high dose ARA-C consolidation cycles. Molecular evaluation of the bone marrow revealed a positivity for CBFB-MYH11 inv(16) (p13;22) fusion transcript. The patient had no identical sibling and unrelated matched donor (UMD) from the Poland registry PL-DKMS (Fundacija DKMS) was

6 white blood cells (WBC) [9]. Mononuclear cells 
activated and the transplantation was performed in November 2018. The myeloablative conditioning regimen with $\mathrm{Bu} / \mathrm{Cy}+\mathrm{ATG}$ (Busulfan $3.2 \mathrm{mg} / \mathrm{kg}$ / day over 4 days -from day -7 to day -4 before allo-HSCT, followed by Cyclophosphamide $60 \mathrm{mg} /$ $\mathrm{kg} /$ day iv for 2 days - days -3 and -2 ) was used [9]. Conventional immunosuppressive therapy with cyclosporine and Seattle protocol was applied [9]. Peripheral blood stem cells (PBSC) were used as graft source in a dose of 4,6 $\times 106 \mathrm{CD} 34+$ cells $/ \mathrm{kg}$. During the post-transplant period, CBFB-MYH11 inv $(16)(\mathrm{p} 13 ; 22)$ was the molecular target for PCRbased MRD assessment. On day +45 of HSCT, an increased MRD load compared to that of the pre-transplant MRD was documented. A decreased Cyclosporine dose of $75 \mathrm{mg}$ per day from the ongoing $100 \mathrm{mg}$ followed. On day +90 of HSCT, negative molecular MRD findings were confirmed and continuously preserved to the last evaluation at +15 months after HSCT. Cyclosporine immunosuppression was discontinued in December 2019, after completing one year of HSCT. The molecular MRD kinetics of CBFB-MYH11 inv(16) (p13;22) in this patient is shown in Figure 2. Complete donor chimerism was first documented on day +90 and maintained to the follow-up cutoff date. As this patient initially manifested extramyeloid presentation of AML, we performed a PET scan assessment after 12 months and +1 year after HSCT and no pathological accumulation or activity were observed. with $\mathrm{Bu} / \mathrm{Cy}+\mathrm{ATG}$ regimen [9]. Unrelated HLA 10/10 identical donor, signed to The German National Bone Marrow Donor Registry (DE-ZKRD) was activated. A total of $5.2 \times 106$ peripheral blood stem cells/ kg were collected. MRD was measured with RT- PCR, starting within the first two months of HSCT - on day +45 and thereafter - every three months. Up to the sixth month of HSCT, relatively steady kinetics of transcript levels was noted, as shown in Figure 2. By gradual reduction of the immunosuppression dose molecular remission was documented after 6 months of HSCT and after +9 months consecutively. Complete donor chimerism was first documented on day +90 and maintained to the final evaluation at +9 months.

\section{Case III}

A 58-year-old woman was diagnosed with myelodysplastic syndrome-refractory anemia (MDS-RA) associated with 5bp deletion in the CEBPA gene in July 2018. Rapid progression into overt acute leukemia was demonstrated 4 months later. Standard induction chemotherapy DA $(3+7)$ wasn't successful and remission was achieved with a second line of FLAG-Ida regimen (fludarabine, $30 \mathrm{mg} / \mathrm{m} 2$ iv for 4 days, cytarabine $2 \mathrm{~g} / \mathrm{m} 2$ iv for 4 days, idarubicin $10 \mathrm{mg} / \mathrm{m} 2$ iv for 3 days and G-CSF from day -1). Two consolidation therapies with high dose ARA-C were administered. MUD HSCT was performed in November 2019. Taking into consid-

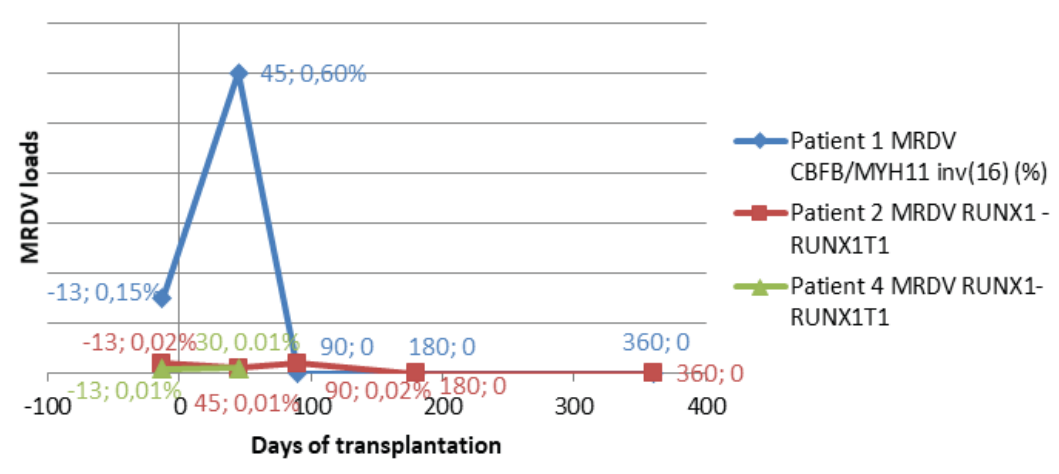

Figure 2. Molecular MRD monitoring of patients with identified chimeric fusion transcripts. MRD kinetics of patients 1, 2 and 4 is marked with blue, red and green curves, respectively.

\section{Case II}

A previously healthy young man at the age of 21 was diagnosed with RUNX1-RUNX1T1 positive AML in January 2019. Remission was achieved after two cycles of DA $(7+3)$ regimen and subsequently two consolidation therapies with a high dose ARA-C were administered. MUD HSCT was performed in August, 2019 after conditioning eration the patient's age, a reduced intensity chemotherapy (RIC) regimen was preferred consisting of Busulfan and Fludarabin + ATG (fludarabine 30 $\mathrm{mg} / \mathrm{m} 2$ iv for 5 days - from -8 to -4 and Busulfan $3.5 \mathrm{mg} / \mathrm{kg} /$ day for 2 days: day -5 and day -4 )[9]. Unrelated HLA 10/10 identical donor from the Italian Bone Marrow Donor Registry (IBMDR) was activated. Peripheral blood stem cells were infused with 
a dose of $6,9 \times 106 \mathrm{CD} 34+$ cells $/ \mathrm{kg}$. MRD was first assessed on day +60 and next, on day +120 and last, on day +150 . Absence of previously detected deletion was confirmed on the first assessment on day +60 coupled with complete donor chimerism.

\section{Case IV}

A 37-year-old woman was diagnosed with RUNX1-RUNX1T1 positive AML in July 2019. Treatment was initiated with DA $(7+3)$ induction regimen and complete remission was established after two induction cycles, followed by two consolidation therapies with a high dose ARA-C. MUD HSCT was performed in January 2020 using a donor form the German National Bone Marrow Donor Registry (DE-ZKRD). Peripheral blood stem cells were administrated with a dose of $9 \times 106 \mathrm{CD} 34+$ cells $/ \mathrm{kg}$ after the myeloablative regimen with $\mathrm{Bu} / \mathrm{Cy}$ + ATG [9]. Conventional immunosuppressive therapy with cyclosporine and metothrexate was started. No significant complications were observed in the early post-transplant period. Bone marrow evaluation was performed at +1 month of HSCT when complete donor chimerism was documented. The patient was MRD positive with MRD loads, nearly equal to those measured in the pre-transplant evaluation $(\mathrm{MRDV}=0.1 \%$ and $\mathrm{MRDV}=0.09 \%$ respectively). On day +38 of HSCT she manifested symptoms of lower gastrointestinal acute GVHD grade III, subsequently confirmed histologically. Immunosuppressive therapy with high dose methylprednisolone was immediately started. Three days later she developed acute severe respiratory syndrome leading to fatal outcome on day +45 of HSCT.

\section{DISCUSSION}

We hereby described our initial experience with 4 AML patients who carried molecular aberration and underwent MUD-HSCT. Regarding the pre-transplant MRD assessment in AML the prognostic significance of MRD status is still uncertain and the time points for MRD assessment are not precisely defined. According to some published data in NPM1-mutated AML $[5,12,13,14]$ estimating the dynamics of MRD loads can be very indicative for the treatment response. However, there is insufficient data on the predicative significance of pre-transplant MRD in other AML molecular subtypes.

The chimeric fusion genes CBFB-MYH11, RUNX1-RUNX1T1, including PML-RAR $\alpha$, rep- resent about $25 \%$ of all AML cases. According to the 2017 risk stratification by the European Leukemia Net, translocation $t(8 ; 21)$ leading to the formation of the RUNX1-RUNX1T1 fusion chimeric gene is considered to be a favorable prognostic marker [15]. Therefore, patients harboring this mutation are not recommended to undergo HSCT in the first $\mathrm{CR}$ although the results from the AML study group show that half of these patients relapse very soon, almost all during the first year of the completion of therapy [16]. In comparison, according to a single center study, among the transplanted patients with RUNX1-RUNX1T1-AML, only $10-20 \%$ are expected to experience relapse [17]. Therefore, our center polices recommend transplant for RUNX1-RUNX1T1 positive AML cases in their CR1. RUNX1-RUNX1T1 transcript is a well-established powerful risk prediction marker for post-transplant relapse and direct future clinical interventions. In line with the same study [15] RUNX1-RUNX1T1 levels kinetics can accurately predict forthcoming relapse but not late relapse, due to the narrow time lag from molecular to morphological relapse. For this reason, time intervals between MRD assessments in these patients should not exceed 3 months.

Acute myeloid leukemia (AML) with inv(16)/ $t(16,16)$, leading to specific CBFBMYH11 fusion transcript formation is also considered as a favorable subtype. Therefore, in terms of transplantation, the same standpoints are held as for RUNX1-RUNX1T1-AML. Due to the general low incidence of this subtype, as well as the lower transplant rate in this group all data originate from small sample-studies. These limited data suggest that post-transplant MRD is predictive of relapse in contrast to pre-transplant MRD. The strongest predictive value is seen at +3 months of HSCT and it is thought that this time period reflects the sensitivity of leukemia cells toward the transplant [19]. In regards to the optimal time intervals between MRD assessments in these patients according to some published data [18] CBFB-MYH11 AML relapses appear to be generally indolent, with the longest delay of 8 months from molecular relapse to hematological evident relapse. However, these findings can not be taken for granted as the study involved non-transplanted patients. Our patient 1 was diagnosed with myeloid sarcoma which stratified him in the adverse risk group. A significantly increased transcript levels were noticed on day +45 of HSCT and we subsequently reduced the dose of Cyclosporine for $25 \%$. Immunosuppressive therapy is designed to prevent GvHD but it 
also inhibits graft-versus leukemia effects (GvL). This patient had no previous signs of GvHD thus he was carefully monitored for possible occurrence of new ones. Our objective was to enhance GvL effects without causing serious GVHD which resulted in achieving MRD negativity at +90 days of HSCT and maintaining it for one year so far in absence of GvHD manifestations.

CEBPA aberrations can be found in up to $10 \%$ of patients with AML. Apart from AML these mutations and deletions can also occur in MDS, multiple myeloma and non-Hodgkin's lymphoma (NHL) patients. CEBPA mutations result in functional block in myeloid differentiation and turning toward the erythroid lineage with consequent erythroid hyperplasia or dysplasia, as was the case with our patient at the time of initial hematological assessment [20]. Most cases of CEBPA-mutant AML are double-mutated and exhibit two mutations while less than one third are single mutants. As for previously published data, double mutants have favorable prognosis, while the prognostic significance of single mutations is still unclear and it is codependent on the presence of additional gene mutations such as FLT3-ITD and NPM1 and it is influenced by the karyotype [20,21].

In addition, in AML, chimerism kinetics seems to be remarkably correlated to MRD kinetics. Since chimerism itself could not be considered as an indirect marker for post-transplant MRD monitoring, it serves more likely as a prognostic factor for impending relapse. Therefore, chimerism analyses should be combined with MRD assessment in order to optimize predictive values.

MRD status can be used to guide future clinical interventions in a post-transplant period. The presence of post- transplant MRD can identify those patients who are unlikely to benefit from re-application of similar therapies because of the selection and expansion of therapy-resistant clones. Different therapy strategies may be adopted in attempt to eliminate MRD ranging from watchful waiting through withdrawal of immunosuppression to more aggressive clinical interventions and they all can be categorized into two general approaches - immunomodulation and chemotherapeuteic agents [22]. Immunomodulation includes donor lymphocyte infusion (DLI) natural killer (NK) cell infusion, both focused on enhancing GvL effects; and chimeric antigen receptors (CAR) T-cells. In addition, the emergence of new chemotherapeutic agents, such as DNA hypomethylating agents and targeted therapies could potentially eradicate MRD positivity.

\section{CONCLUSION}

In our experience, when molecularly-defined AML patients undergo HSCT, regular MRD monitoring helps predict impending relapse and direct future treatment strategies. RT-PCR post-transplant molecular monitoring is of twofold significance:

- predicting impending relapse and

- guiding future MRD-based decisions and treatment strategies.

In patients undergoing allogeneic HSCT, MRD should be evaluated within a month prior to the start of the conditioning regimen. During the follow-up period, MRD should be monitored every three months in a BM sample for at least two years and according to individual risk thereafter.

An MRD status itself is not a conclusive or sufficient criterion to decide whether to intervene therapeutically. The main questions remain whether, when and at what threshold a clinical intervention is required. Well-designed prospective clinical trials are needed to answer these questions and establish MRD- guided clinical protocols.

\section{REFERENCES}

1. Loke J, Malladi R, Moss P, Craddock C. The role of allogeneic stem cell transplantation in the management of acute myeloid leukaemia: a triumph of hope and experience. Br J Haematol. 2020;188(1):129-146. doi:10.1111/bjh.16355

2. Horowitz, M., Schreiber, H., Elder, A. et al. Epidemiology and biology of relapse after stem cell transplantation. Bone Marrow Transplant 53, 1379-1389 (2018). https://doi.org/10.1038/ s41409-018-0171-z

3. Schuurhuis GJ, Heuser M, Freeman S, at el. Minimal/measurable residual disease in AML: consensus document from ELN MRD Working Party. Blood. 2018; 131(12): 1275-91. https:// doi.org/10.1182/blood-2017-09-801498

4. Döhner H, Estey E, Grimwade D, et al. Diagnosis and management of AML in adults: 2017 ELN recommendations from an internation- 
al expert panel. Blood. 2017;129(4): 424-447. doi:10.1182/blood-2016-08-733196

5. Khanal, Nabin \& Banskota, Shristi \& Bhatt, Vijaya. (2020). Novel treatment paradigms in acute myeloid leukemia. Clinical Pharmacology \& Therapeutics. 10.1002/cpt.1962.

6. Dillon R, Hills R, Freeman S, et al. Molecular MRD status and outcome after transplantation in NPM1-mutated AML. Blood. 2020; 135(9): 680-688. doi:10.1182/blood.2019002959

7. Rovira M, Suárez-Lledó M. Short- and LongTerm Controls After HSCT. In: Carreras E, Dufour C, Mohty M, Kröger N, eds. The EBMT Handbook: Hematopoietic Stem Cell Transplantation and Cellular Therapies. 7th ed. Cham (CH): Springer; 2019: 149-153.

8. Cheson BD, Bennett JM, Kopecky KJ, et al. Revised recommendations of the International Working Group for Diagnosis, Standardization of Response Criteria, Treatment Outcomes, and Reporting Standards for Therapeutic Trials in Acute Myeloid Leukemia., J Clin Oncol, 2003, vol. 21: 4642-4649.

9. Bacigalupo A, Ballen K, Rizzo D, et al. Defining the intensity of conditioning regimens: working definitions. Biol Blood Marrow Transplant. 2009; 15(12): 1628-1633. doi:10.1016/j. bbmt.2009.07.004

10. Gabert J, Beillard E, van der Velden VH, et al. Standardization and quality control studies of 'real-time' quantitative reverse transcriptase polymerase chain reaction of fusion gene transcripts for residual disease detection in leukemia - a Europe Against Cancer program. Leukemia. 2003;17(12):2318-2357. doi:10.1038/ sj.leu.2403135

11. Claire L. Green, Kenneth K. Koo, Robert K. Hills, Alan K. Burnett, David C. Linch, and Rosemary E. Gale Prognostic Significance of CEBPA Mutations in a Large Cohort of Younger Adult Patients With Acute Myeloid Leukemia: Impact of Double CEBPA Mutations and the Interaction With FLT3 and NPM1 Mutations J Clin Oncol.2010; 28: 2739-2747

12. Jentzsch M, Schwind S, Bach E, Stasik S, Thiede C, Platzbecker U. Clinical Challenges and Consequences of Measurable Residual Disease in Non-APL Acute Myeloid Leukemia. Cancers (Basel). 2019; 11(11): 1625. Published 2019 Oct 23. doi: $10.3390 /$ cancers 11111625

13. Balsat M, Renneville A, Thomas X, et al. Postinduction Minimal Residual Disease Predicts Outcome and Benefit From Allogeneic Stem Cell Transplantation in Acute Myeloid Leukemia With NPM1 Mutation: A Study by the Acute Leukemia French Association Group. J Clin Oncol. 2017; 35(2): 185-193. doi:10.1200/ JCO.2016.67.1875
14. Kayser S, Benner A, Thiede C, et al. Pretransplant NPM1 MRD levels predict outcome after allogeneic hematopoietic stem cell transplantation in patients with acute myeloid leukemia. Blood Cancer J. 2016; 6(7): e449. Published 2016 Jul 29. doi:10.1038/bcj.2016.46

15. Qin YZ, Wang Y, Xu LP, et al. The dynamics of RUNX1-RUNX1T1 transcript levels after allogeneic hematopoietic stem cell transplantation predict relapse in patients with $\mathrm{t}(8 ; 21)$ acute myeloid leukemia. J Hematol Oncol. 2017; 10(1): 44. Published 2017 Feb 6. doi:10.1186/s13045017-0414-2

16. Zhu HH, Zhang XH, Qin YZ, et al. MRD-directed risk stratification treatment may improve outcomes of $\mathrm{t}(8 ; 21)$ AML in the first complete remission: results from the AML05 multicenter trial. Blood. 2013; 121(20): 4056-4062. doi:10.1182/ blood-2012-11-468348

17. Rücker FG, Agrawal M, Corbacioglu A, et al. Measurable residual disease monitoring in acute myeloid leukemia with $\mathrm{t}(8 ; 21)(\mathrm{q} 22 ; \mathrm{q} 22.1)$ : results from the AML Study Group. Blood. 2019; 134(19): 1608-1618. doi:10.1182/ blood.2019001425

18. Tang FF, Xu LP, Zhang XH, et al. Monitoring of post-transplant CBFB-MYH11 as minimal residual disease, rather than KIT mutations, can predict relapse after allogeneic haematopoietic cell transplantation in adults with inv(16) acute myeloid leukaemia. Br J Haematol. 2018; 180(3): 448-451. doi:10.1111/bjh. 14340

19. Ommen HB, Schnittger S, Jovanovic JV, et al. Strikingly different molecular relapse kinetics in NPM1c, PML-RARA, RUNX1-RUNX1T1, and CBFB-MYH11 acute myeloid leukemias. Blood. 2010; 115(2): 198-205. doi:10.1182/ blood-2009-04-212530

20. Mannelli F, Ponziani V, Bencini S, et al. CEBPA-double-mutated acute myeloid leukemia displays a unique phenotypic profile: a reliable screening method and insight into biologicalfeatures. Haematologica.2017; 102(3): 529-540. doi:10.3324/haematol.2016.151910

21. Green CL, Koo KK, Hills RK, Burnett AK, Linch DC, Gale RE. Prognostic significance of CEBPA mutations in a large cohort of younger adult patients with acute myeloid leukemia: impact of double CEBPA mutations and the interaction with FLT3 and NPM1 mutations. J Clin Oncol. 2010; 28(16): 2739-2747. doi:10.1200/ JCO.2009.26.2501

22. Rein LA, Sung AD, Rizzieri DA. New approaches to manipulate minimal residual disease after allogeneic stem cell transplantation. IntJHematolOncol. 2013; 2(1): 10.2217/ijh.13.4. doi:10.2217/ijh.13.4 


\title{
Резиме
}

\section{МОЛЕКУЛАРНО СЛЕДЕЊЕ НА ПАЦИЕНТИТЕ СО АКУТНА МИЕЛОИДНА ЛЕКЕМИЈА ЛЕКУВАНИ СО ИДЕНТИЧНА НЕСРОДНА ТРАНСПЛАНТАЦИЈА НА МАТИЧНИ ХЕМАТОПОЕТСКИ КЛЕТКИ: ИСКУСТВА ОД ЕДЕН ЦЕНТАР}

\author{
Ирина Пановска-Ставридис ${ }^{1}$, Александра Пивкова-Велјановска ${ }^{1}$, Невенка Ридова ${ }^{1}$, \\ Злате Стојановски ${ }^{1}$, Лазар Чадиевски ${ }^{1}$, Сања Трајкова ${ }^{1}$, Марија Попова-Лабачевска ${ }^{1}$, \\ Надица Матевска-Гешковска², Лидија Чевреска ${ }^{1}$, Борче Георгиевски ${ }^{1}$, Александар Димовски ${ }^{2,3}$ \\ ${ }^{1}$ Универзитетска клиника за хематологија-Скопје, РС Македонија \\ ${ }^{2}$ Центар за биомолекуларни фармацевтски анализи, Фармацевтски факултет, Универзитет „Св. \\ Кирил и Методиј“, Скопје, РС Македонија \\ ${ }^{3}$ Истражувачки центар за генетско инженерство и биотехнологија „Георги Д. Ефремов“, \\ Македонска академија на науките и уметностите, Скопје, РС Македонија
}

Вовед: Процената на минималната резидуална болест (МРД) кај пациентите со акутната миелоидна леукемија (АМЛ) претставува комплексен мутимодален процес и, иако неговата клиничка примена е обемно евалуирана, таа сѐ уште преставува предизвик за клиничарите. Применетиот модалитет за процена на МРД зависи од биологијата на болеста: високо сензитивни техники за евалуација на МРД може да се применат кај пациентите што носат специфични молекуларни маркери. Од друга страна, релапсот се смета за водечка причина за неуспех во третманот кај пациентите со АМЛ лекувани со алогена трансплантација на матични хематопоетски клетки (ТМХК).

Материјал и методи: Во периодот од ноември 2018 до јуни 2020 година, 10 пациенти со АМЛ беа лекувани со несродна (МУД)-ТМХК на Универзитетската клиника за хематологија Скопје, РС Македонија. Молекуларни маркери беа идентификувани кај четворица од нив: тројца пациенти експримираа фузиски траснкрипти, двајца RUNX-RUNX1T1, а еден CBFB-MYH11. Четвртиот пациент имаше мутација во транскрипцискиот фактор CEBPA. Посттрансплантациска МРД кинетика беше евалуирана со примена на квантитативна полимераза верижна реакција (RT-qPCR) или мултиплекс флуоресцентна PCR, секои три месеци по трансплантација.

Резултати: МРД негативитет беше постигнат кај тројца пациенти, кои пред трансплантација беа МРД-позитивни, и тоа најдоцна 6 месеци по ТМХК. Овие пациенти сѐ уште се во молекуларна ремисија 7, 9 и 19 месеци по интервенцијата. Четвртиот пациент почина како резултат на компликации поврзани со трансплантацијата .

Заклучок: Нашето искуство укажува дека кај пациентите со молекуларно дефинирани АМЛ по ТМХК, редовното следење на МРД помага да се детектира придружниот релапс и овозможува правилно водење на понатамошната тераписка стратегија.

Клучни зборови: минимална резидуална болест (МРД), молекуларно следење, идентична несродна трансплантација (ИНТ), трансплантација на матични хематопоетски клетки (ТМХК), акутна миелодина леукемија (АМЛ), RUNX-RUNX1T1, CBFB-MYH11, CEBPA 